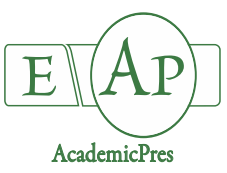

Yarali Karakan F (2020)
Notulae Botanicae Horti Agrobotanici Cluj-Napoca 48(3):1176-1184
DOI: $10.15835 /$ nbha48311964
Research Article

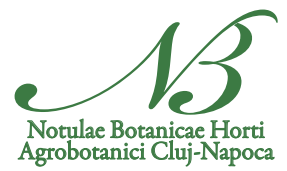

\title{
The genotypic response towards haploid induction in Turkish onion (Allium cepa L.) germplasm
}

\author{
Faika YARALI KARAKAN
}

University of Kilis 7 Aralik, Faculty of Agriculture, Department of Horticulture, 79000, Kilis, Turkey; faikayarali@gmail.com

\begin{abstract}
Haploid induction efficiency of unpollinated flower buds in twenty-six Turkish onion germplasm were determined on two media, Dunstan and Short medium (BDS) and Murashige and Skoog's medium (MS). On BDS medium, 5850 flower buds were cultured and the induction rate was $2.10 \%$ and a plant survival percentage of $1.62 \%$ ( 2 plants). On MS medium, 5850 flower buds were cultured and 175 plantlets were induced; induction rate was $2.99 \%$ and plant survival percentage was $13.71 \%$ (24 plants). The highest number of plantlets was obtained from genotype Sanliurfa 2; 27 plantlets on BDS medium while 45 plantlets on MS medium. Flow cytometry confirmed that out of the twenty-six plants, 4 plants were haploid $(15.38 \%), 2$ mixoploid (7.69\%), 18 (69.23\%) diploid and 2 tetraploid (7.69\%).
\end{abstract}

Keywords: Allium cepa; BDS medium; flow cytometry; gynogenesis; MS medium

\section{Introduction}

Onion is one of the most important crops cultivated and consumed all around the world as a vegetable, spice and medicinal food. Most of the commercially grown onion cultivars are open-pollinated (OP) or F1 hybrid. Hybrid cultivars are considered to be superior contrary to open-pollinated cultivars, because of their higher yield and more desired $\mathrm{m}$ marketable crop. Therefore, there is a strong demand for F1 hybrids (Alan et al., 2017; Mathapati et al., 2019). In order to develop of hybrid varieties, three kinds of parental lines are required; male-sterile parent (A line), maintenance parent (B line) for maintaining male sterility, and pollen parent ( $\mathrm{C}$ line). To develop inbreeds in the three lines, backcross breeding and line selection method using selfing have been mainly used. However, it is difficult to obtain inbred lines, since the onion plants have severe inbreeding depression. Furthermore, onion has a biennial life cycle and thus at least 6-10 years are required to produce inbred lines. In onion, the gynogenesis-based doubled-haploid (DH) technique can provide completely homozygous lines in one generation. Medium composition and genotype are critical factor affecting haploid production in onion. BDS (Dunstan and Short, 1977), MS (Murashige and Skoog, 1962) and Gamborg's (B5) medium (Gamborg et al., 1968) supplemented with 2,4-dichlorophenoxyacetic acid (2,4-D) and 6-benzyl-aminopurine (BA) at $2 \mathrm{mgl}^{-1}$ is widely used basal medium (Alan et al., 2003; Jakse et al., 2010; Yarali and Yanmaz, 2013; Yarali and Yanmaz, 2017; Khar et al., 2018; Yarali Karakan, 2019).

Genotypic effect of donor plant plays the most important roles to succeed at gynogenesis in onion therefore the percentage of gynogenic haploid embryos, embryo quality and embryo regeneration varies

Received: 15 Jun 2020. Received in revised form: 23 Jul 2020. Accepted: 14 Aug 2020. Published online: 25 Aug 2020. 
according to species and varieties (Bohanec and Jakse 1999; Anandhan et al., 2014; Dhatt and Thakur, 2014; Sahinalp and Yarali Karakan, 2019). Though there were many reports on gynogenesis in onion from genotypes of different geographical origin in the world but report on Turkish group is limited (Yarali and Yanmaz, 2017). Therefore, characterizing Turkish germplasm for gynogenic potential becomes imperative, so these genotypes will be useful for developing mapping population, breeding programs and also useful for genetic studies on gynogenesis. In the present study, it was aimed to determine the variation in gynogenic potential in some Turkish onion germplasm.

\section{Materials and Methods}

\section{Plant material and sterilization processes}

This work was carried out during the years 2017 to 2018 at University of Kilis 7 Aralik, Advanced Technology Application and Research Center. Thirteen locally grown onion genotypes ('Adana', 'Amasya 1', 'Amasya 2', 'Bismil', 'Hatay', 'Islahiye', 'Kilis 1', 'Kilis 2', 'Kilis 3', 'Musabeyli', 'Nizip', 'Sanliurfa 1', 'Sanliurfa 2') from different province of Turkey and thirteen open-pollinated onion cultivars ('Aypare', 'Bereket', 'Beyazbilek', 'Burgaz 10', 'Damla', 'Edis', 'Gence', 'Haktan', 'Hediye', 'MT-300', 'Sampiyon', 'Taraz', and 'Yanki') were used as plant material. Bulbs of onion cultivars and genotypes were grown at the Agricultural Application and Research Center of Kilis 7 Aralik University to obtain flower buds for the laboratory works. Whole umbels were harvested before anthesis and sterilized by soaking for $3 \mathrm{~min}$. in $70 \%$ ethanol, then sterilized for $30 \mathrm{~min}$. in 15\% clorox and rinsed three times with sterile distilled water (Yarali and Yanmaz, 2017).

\section{In vitro culture and ploidy analysis}

BDS medium and MS basal medium supplemented with $2 \mathrm{mg} \mathrm{l}^{1-1}$ of 2,4-D (2,4-Dichlorophenoxyacetic acid) and $2 \mathrm{mg} \mathrm{l}^{-1}$ of BAP (6-Benzylaminopurine) were used as induction medium. All media were adjusted to $\mathrm{pH} 6.0$ and were solidified with $7.2 \mathrm{~g} \mathrm{l}^{-1}$ phytagar and autoclaved at $121^{\circ} \mathrm{C}$ for $20 \mathrm{~min}$. Flower buds were placed in the induction medium. Each treatment included fifteen replications, each replicate (dish) containing 15 flower buds. The dishes were sealed with stretch film and incubated at $25^{\circ} \mathrm{C}$ under $16 / 8$ h photoperiod. Growing explants were transferred to elongation medium (EM) (Yarali and Yanmaz, 2017). Ploidy level determined by Flow Cytometry (FCM) according to the protocol published by Alan et al. (2007).

\section{Statistical analysis}

All experiment was designed according to Completely Randomized Design (CRD). The number of flower buds, callus induction, hyperhydric, plumpy (enlarged buds), contaminated and non-responsive (dead) and induced plantlets were recorded. Data were analyzed one-way analysis of variance followed by Tukey's $(p \leq 0.05)$ Honest Significant Difference (HSD) test and the t-test was applied with JMP software version (5.0.1).

\section{Results}

According to the variance analysis, effects of "culture media $\times$ genotype" interaction were significant $(\mathrm{p} \leq 0.05)$ on enlarged buds (plumpy), callus formation and induced plantlets (Table 1). As seen in Table 1, percentage of induced plantlets was changed between $0 \%$ and $20 \%$. The highest percentage of induced plantlets was observed as $12 \%$ and $20 \%$, the highest percentage of callus induction was $20 \%$ and $21.8 \%$ on BDS and MS medium, respectively. Whereas the highest number of plumpy buds were recorded as $95.6 \%$ and $83.6 \%$ on MS medium and BDS medium, respectively. Hyperhydricity, also referred to as 'vitrification' or 'glassiness', is a 
physiological disorder and flower buds appear watery in texture. The highest hyperhydricity was observed 63.1\% and $46.2 \%$ on BDS and MS medium, respectively (Figure 1 and Figure 2). On BDS medium, 5850 flower buds were cultured and 123 plantlets were induced (Figure 3). The induction rate was calculated as $2.10 \%$ and a plant survival percentage of $1.14 \%$ (two plants) according to the number of plantlets as seen in Figure 3. On MS medium, 5850 flower buds were cultured and 175 plantlets (2.99\%) were induced and the percentage of plant survival was $13.71 \%$ (24 plants).

Regarding percentage of gynogenic induction, callus formation and enlarged buds (plumpy) varied according to locally grown genotypes and open-pollinated onion cultivars. Both the highest percentage of induced plantlets (20\%) and callus induction (21.8\%) were observed in Sanliurfa 2, while the highest number of plumpy buds was recorded at $95.6 \%$ in Nizip (Table 1). As evident from Figure 3, the highest numbers of induced plantlets were obtained from 'Sanliurfa 2' as 27 plantlets on BDS medium and 45 plantlets on MS medium. The highest hyperhydricity was found in Kilis 2 as 63.1\% (Figure 1 and Figure 2).

Totally two hundred ninety-eight plantlets (298) obtained from different onion genotypes on MS and BDS medium and $26(8.72 \%)$ plants survived in this research. Concerning to the ploidy analyses, 4 plants (15.38\%) were haploid (n), 2 plants (7.69\%) were mixoploid $(n+2 n$ and $2 n+4 n), 18$ plants $(69.23 \%)$ were diploid (2n) and 2 plants (7.69\%) were tetraploid (4n) (Figure 4). All haploid plants were obtained from the 'Sanliurfa 2' genotype. The stages of haploidy induction are given in the Figure 5.

Table 1. The effect of genotype and culture media on the number of plumpy buds, callus induction and induced plantlets (per dish)

\begin{tabular}{|c|c|c|c|c|c|c|}
\hline \multirow[b]{2}{*}{ Genotypes } & \multicolumn{6}{|c|}{ BDS Medium } \\
\hline & $\begin{array}{c}\text { No of plumpy } \\
\text { buds }\end{array}$ & $\begin{array}{c}\text { Percent of } \\
\text { plumpy buds } \\
(\%)\end{array}$ & $\begin{array}{l}\text { No of callus } \\
\text { per dish }\end{array}$ & $\begin{array}{l}\text { Percent of } \\
\text { callus } \\
(\%)\end{array}$ & $\begin{array}{c}\text { No of } \\
\text { plantlets }\end{array}$ & $\begin{array}{c}\text { Percent of } \\
\text { plantlets } \\
(\%)\end{array}$ \\
\hline 'Adana' & $10.80 \mathrm{~b}-\mathrm{h}$ & 72.0 & $0.26 \mathrm{hi}$ & 1.8 & $0.00 \mathrm{i}$ & 0.0 \\
\hline 'Amasya 1' & $9.73 \mathrm{c}-\mathrm{k}$ & 64.9 & $0.33 \mathrm{hi}$ & 2.2 & $0.00 \mathrm{i}$ & 0.0 \\
\hline 'Amasya 2' & $7.40 \mathrm{k}-\mathrm{o}$ & 49.3 & $1.20 \mathrm{~d}-\mathrm{i}$ & 8.0 & $1.53 \mathrm{~b}-\mathrm{d}$ & 10.2 \\
\hline 'Aypare' & $10.73 \mathrm{~b}-\mathrm{i}$ & 71.6 & $2.93 \mathrm{ab}$ & 19.6 & $1.00 \mathrm{c}-\mathrm{g}$ & 6.7 \\
\hline 'Bereket' & $3.66 \mathrm{p}-\mathrm{q}$ & 24.4 & $0.00 \mathrm{i}$ & 0.0 & $0.00 \mathrm{i}$ & 0.0 \\
\hline 'Beyazbilek' & $11.06 \mathrm{~b}-\mathrm{g}$ & 73.8 & $3.00 \mathrm{ab}$ & 20.0 & $0.26 \mathrm{f}-\mathrm{i}$ & 1.8 \\
\hline 'Bismil' & $11.40 \mathrm{~b}-\mathrm{f}$ & 76.0 & $2.40 \mathrm{a}-\mathrm{d}$ & 16.0 & $0.40 \mathrm{e}-\mathrm{i}$ & 2.7 \\
\hline 'Burgaz 10' & $3.26 \mathrm{q}$ & 21.8 & $1.46 c-h$ & 9.8 & $0.13 \mathrm{hi}$ & 0.9 \\
\hline 'Damla' & $9.00 \mathrm{e}-1$ & 60.0 & $0.53 \mathrm{~g}-\mathrm{i}$ & 3.6 & $0.00 \mathrm{i}$ & 0.0 \\
\hline 'Edis' & $11.66 \mathrm{a}-\mathrm{e}$ & 77.8 & $1.00 \mathrm{e}-\mathrm{i}$ & 6.7 & $1.00 \mathrm{c}-\mathrm{g}$ & 6.7 \\
\hline 'Gence' & $5.66 n-q$ & 37.8 & $0.00 \mathrm{i}$ & 0.0 & $0.00 \mathrm{i}$ & 0.0 \\
\hline 'Haktan' & $0.00 \mathrm{r}$ & 0.0 & $0.00 \mathrm{i}$ & 0.0 & $0.00 \mathrm{i}$ & 0.0 \\
\hline 'Hatay' & $0.00 \mathrm{r}$ & 0.0 & $0.00 \mathrm{i}$ & 0.0 & $0.00 \mathrm{i}$ & 0.0 \\
\hline 'Hediye' & $0.33 \mathrm{r}$ & 2.2 & $0.00 \mathrm{i}$ & 0.0 & $0.00 \mathrm{i}$ & 0.0 \\
\hline 'Islahiye' & $9.46 \mathrm{~d}-\mathrm{k}$ & 63.1 & $2.46 \mathrm{a}-\mathrm{d}$ & 16.4 & $0.66 \mathrm{e}-\mathrm{i}$ & 4.4 \\
\hline 'Kilis 1' & $6.00 \mathrm{~m}-\mathrm{q}$ & 40.0 & $0.26 \mathrm{hi}$ & 1.8 & $0.40 \mathrm{e}-\mathrm{i}$ & 2.7 \\
\hline 'Kilis 2' & $12.53 \mathrm{a}-\mathrm{c}$ & 83.6 & $0.80 \mathrm{e}-\mathrm{i}$ & 5.3 & $0.33 \mathrm{f}-\mathrm{i}$ & 2.2 \\
\hline 'Kilis 3' & $4.06 \mathrm{p}-\mathrm{q}$ & 27.1 & $0.00 \mathrm{i}$ & 0.0 & $0.00 \mathrm{i}$ & 0.0 \\
\hline 'Musabeyli' & $9.66 \mathrm{~d}-\mathrm{k}$ & 64.4 & 0.26 hi & 1.8 & $0.20 \mathrm{~g}-\mathrm{i}$ & 1.3 \\
\hline 'MT-300' & $0.00 \mathrm{r}$ & 0.0 & $0.00 \mathrm{i}$ & 0.0 & $0.00 \mathrm{i}$ & 0.0 \\
\hline 'Nizip' & $6.331-p$ & 42.2 & $0.40 \mathrm{hi}$ & 2.7 & $0.06 \mathrm{hi}$ & 0.4 \\
\hline 'Sanliurfa 1' & $8.86 \mathrm{e}-1$ & 59.1 & $0.80 \mathrm{e}-\mathrm{i}$ & 5.3 & $0.00 \mathrm{i}$ & 0.0 \\
\hline 'Sanliurfa 2' & $12.20 \mathrm{a}-\mathrm{d}$ & 81.3 & $2.00 \mathrm{a}-\mathrm{e}$ & 13.3 & $1.80 \mathrm{bc}$ & 12.0 \\
\hline 'Sampiyon' & $7.93 \mathrm{I}-\mathrm{o}$ & 52.9 & $0.66 \mathrm{e}-\mathrm{i}$ & 4.4 & $0.20 \mathrm{~g}-\mathrm{i}$ & 1.3 \\
\hline 'Taraz' & 8.46 g-n & 56.4 & $0.00 \mathrm{i}$ & 0.0 & $0.00 \mathrm{i}$ & 0.0 \\
\hline 'Yanki' & $7.60 \mathrm{k}-\mathrm{o}$ & 50.7 & $0.60 \mathrm{f}-\mathrm{i}$ & 4.0 & $0.20 \mathrm{~g}-\mathrm{i}$ & 1.3 \\
\hline
\end{tabular}


Yarali Karakan F (2020). Not Bot Horti Agrobo 48(3):1176-1184

\begin{tabular}{|c|c|c|c|c|c|c|}
\hline \multirow{2}{*}{$\begin{array}{c}\text { Genotypes } \\
\text { 'Adana' }\end{array}$} & \multicolumn{6}{|c|}{ MS Medium } \\
\hline & $7.93 \mathrm{i}-\mathrm{o}$ & 52.9 & $0.33 \mathrm{hi}$ & 2.2 & $0.26 \mathrm{f}-\mathrm{i}$ & 1.8 \\
\hline 'Amasya 1' & $8.13 \mathrm{~h}-\mathrm{o}$ & 54.2 & $0.80 \mathrm{e}-\mathrm{i}$ & 5.3 & $0.00 \mathrm{i}$ & 0.0 \\
\hline 'Amasya 2' & $7.33 \mathrm{k}-\mathrm{o}$ & 48.9 & $1.40 \mathrm{c}-\mathrm{h}$ & 9.3 & $1.93 \mathrm{~b}$ & 12.9 \\
\hline 'Aypare' & $7.86 \mathrm{j}-\mathrm{o}$ & 52.4 & $3.00 \mathrm{ab}$ & 20.0 & $1.20 \mathrm{~b}-\mathrm{e}$ & 8.0 \\
\hline 'Bereket' & $0.00 \mathrm{r}$ & 0.0 & $0.00 \mathrm{i}$ & 0.0 & $0.00 \mathrm{i}$ & 0.0 \\
\hline 'Beyazbilek' & $9.60 \mathrm{~d}-\mathrm{k}$ & 64.0 & $1.80 \mathrm{~b}-\mathrm{g}$ & 12.0 & $1.06 \mathrm{c}-\mathrm{f}$ & 7.1 \\
\hline 'Bismil' & $8.40 \mathrm{~g}-\mathrm{n}$ & 56.0 & $2.60 \mathrm{a}-\mathrm{c}$ & 17.3 & $0.20 \mathrm{~g}-\mathrm{i}$ & 1.3 \\
\hline 'Burgaz 10' & $10.00 \mathrm{c}-\mathrm{k}$ & 66.7 & $1.00 \mathrm{e}-\mathrm{i}$ & 6.7 & $0.46 \mathrm{e}-\mathrm{i}$ & 3.1 \\
\hline 'Damla' & $11.06 \mathrm{~b}-\mathrm{g}$ & 73.8 & $0.20 \mathrm{hi}$ & 1.3 & $0.06 \mathrm{hi}$ & 0.4 \\
\hline 'Edis' & $12.86 \mathrm{ab}$ & 85.8 & $3.00 \mathrm{ab}$ & 20.0 & $0.53 \mathrm{e}-\mathrm{i}$ & 3.6 \\
\hline 'Gence' & $3.60 \mathrm{p}-\mathrm{q}$ & 24.0 & $0.40 \mathrm{hi}$ & 2.7 & $0.00 \mathrm{i}$ & 0.0 \\
\hline 'Haktan' & $0.00 \mathrm{r}$ & 0.0 & $0.00 \mathrm{i}$ & 0.0 & $0.00 \mathrm{i}$ & 0.0 \\
\hline 'Hatay' & $0.00 \mathrm{r}$ & 0.0 & $0.00 \mathrm{i}$ & 0.0 & $0.00 \mathrm{i}$ & 0.0 \\
\hline 'Hediye' & $0.00 \mathrm{r}$ & 0.0 & $0.00 \mathrm{i}$ & 0.0 & $0.00 \mathrm{i}$ & 0.0 \\
\hline 'Islahiye' & $10.66 \mathrm{~b}-\mathrm{j}$ & 71.1 & $1.00 \mathrm{e}-\mathrm{i}$ & 12.9 & $0.33 \mathrm{f}-\mathrm{i}$ & 2.2 \\
\hline 'Kilis 1' & $0.00 \mathrm{r}$ & 0.0 & $0.00 \mathrm{i}$ & 0.0 & $0.00 \mathrm{i}$ & 0.0 \\
\hline 'Kilis 2' & $10.80 \mathrm{~b}-\mathrm{h}$ & 72.0 & $0.46 \mathrm{~g}-\mathrm{i}$ & 7.6 & $0.33 \mathrm{f}-\mathrm{i}$ & 2.2 \\
\hline 'Kilis 3' & $8.60 \mathrm{f}-\mathrm{m}$ & 57.3 & $1.00 \mathrm{e}-\mathrm{i}$ & 6.7 & $0.00 \mathrm{i}$ & 0.0 \\
\hline 'Musabeyli' & 8.00 h-o & 53.3 & $1.46 \mathrm{c}-\mathrm{h}$ & 9.8 & $0.20 \mathrm{~g}-\mathrm{i}$ & 4.9 \\
\hline 'MT-300' & $0.00 \mathrm{r}$ & 0.0 & $0.00 \mathrm{i}$ & 0.0 & $0.00 \mathrm{i}$ & 0.0 \\
\hline 'Nizip' & $14.33 \mathrm{a}$ & 95.6 & $0.60 \mathrm{f}-\mathrm{i}$ & 4.0 & $0.13 \mathrm{hi}$ & 0.9 \\
\hline 'Sanliurfa 1' & $5.33 \mathrm{o}-\mathrm{q}$ & 35.6 & $1.26 \mathrm{c}-\mathrm{i}$ & 13.8 & $0.00 \mathrm{i}$ & 0.0 \\
\hline 'Sanliurfa 2' & $9.46 \mathrm{~d}-\mathrm{k}$ & 63.1 & $3.26 \mathrm{a}$ & 21.8 & $3.00 \mathrm{a}$ & 20.0 \\
\hline 'Sampiyon' & $5.53 \mathrm{o}-\mathrm{q}$ & 36.9 & $2.86 \mathrm{ab}$ & 19.1 & $0.53 \mathrm{e}-\mathrm{i}$ & 3.6 \\
\hline 'Taraz' & 8.13 h-o & 54.2 & $0.40 \mathrm{hi}$ & 2.7 & $0.00 \mathrm{i}$ & 0.0 \\
\hline 'Yanki' & $10.13 \mathrm{~b}-\mathrm{k}$ & 67.6 & $1.93 \mathrm{a}-\mathrm{f}$ & 12.9 & $0.86 \mathrm{~d}-\mathrm{h}$ & 5.8 \\
\hline
\end{tabular}

Levels not connected by same letter are significantly different (Tukey tests, $\mathrm{p} \leq 0.05$ ).

BDS Medium

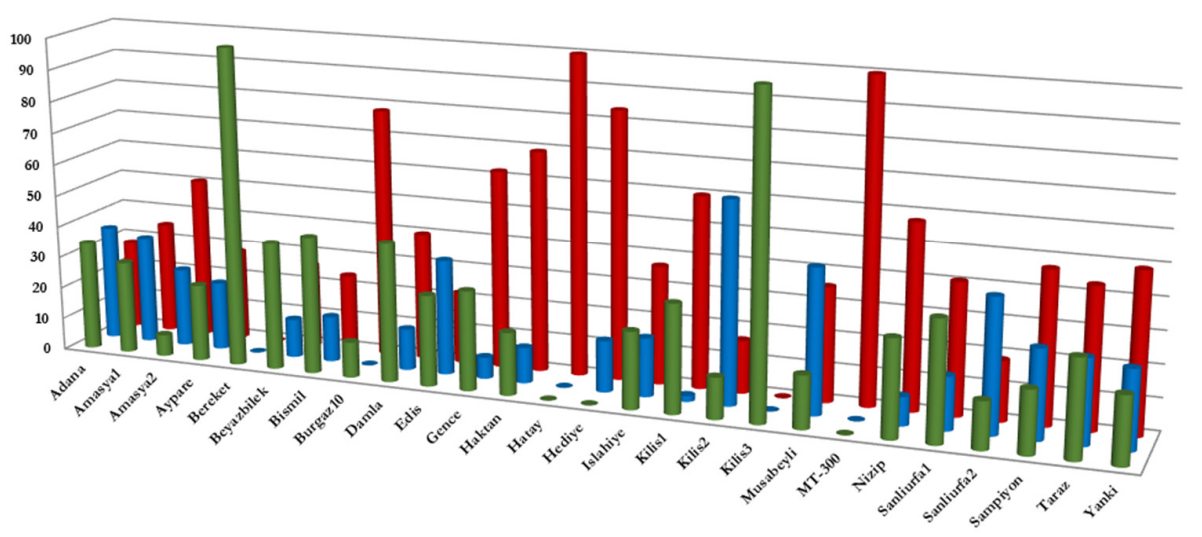

@ Contamined buds (\%) \ $\quad$ Hyperhydricity (\%) $\quad$ Non-responsive buds (\%)

Figure 1. The percentage of hyperhydric, contaminated and non-responsive (dead) flower buds on BDS medium 
MS Medium

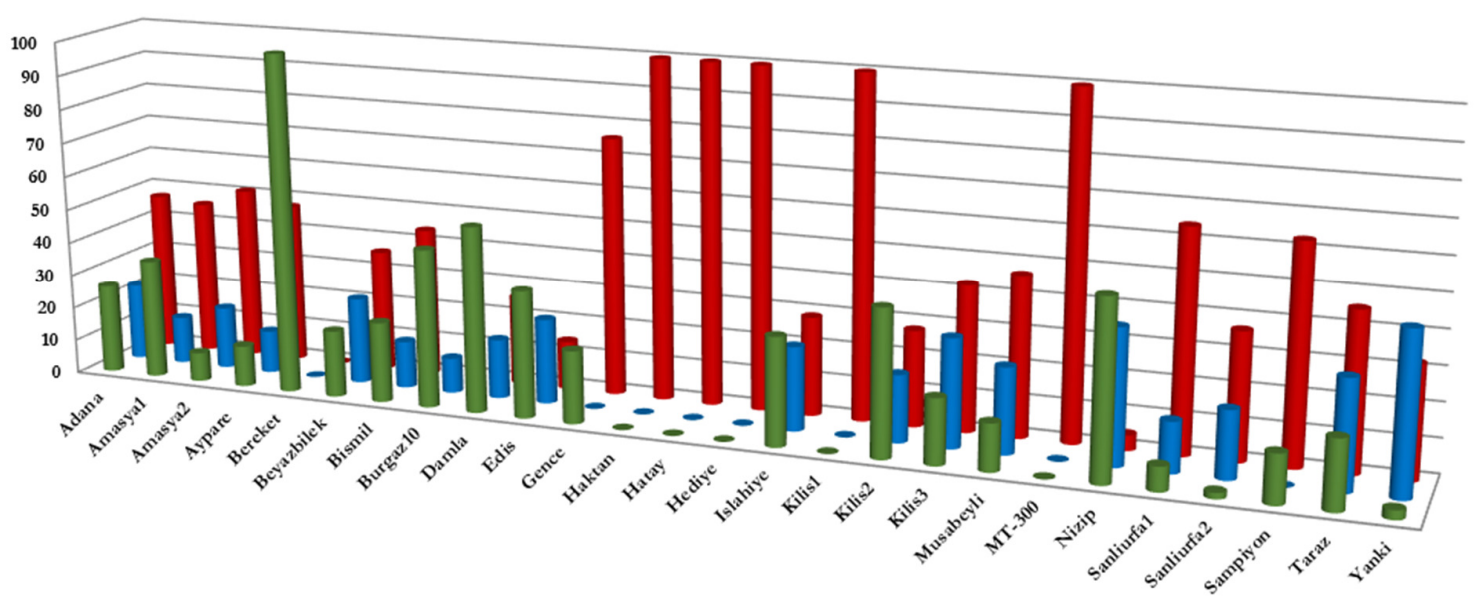

n Contamined buds (\%) $\quad$ - Hyperhydricity (\%) Non-responsive buds (\%)

Figure 2. The percentage of hyperhydric, contaminated and non-responsive (dead) flower buds on MS medium

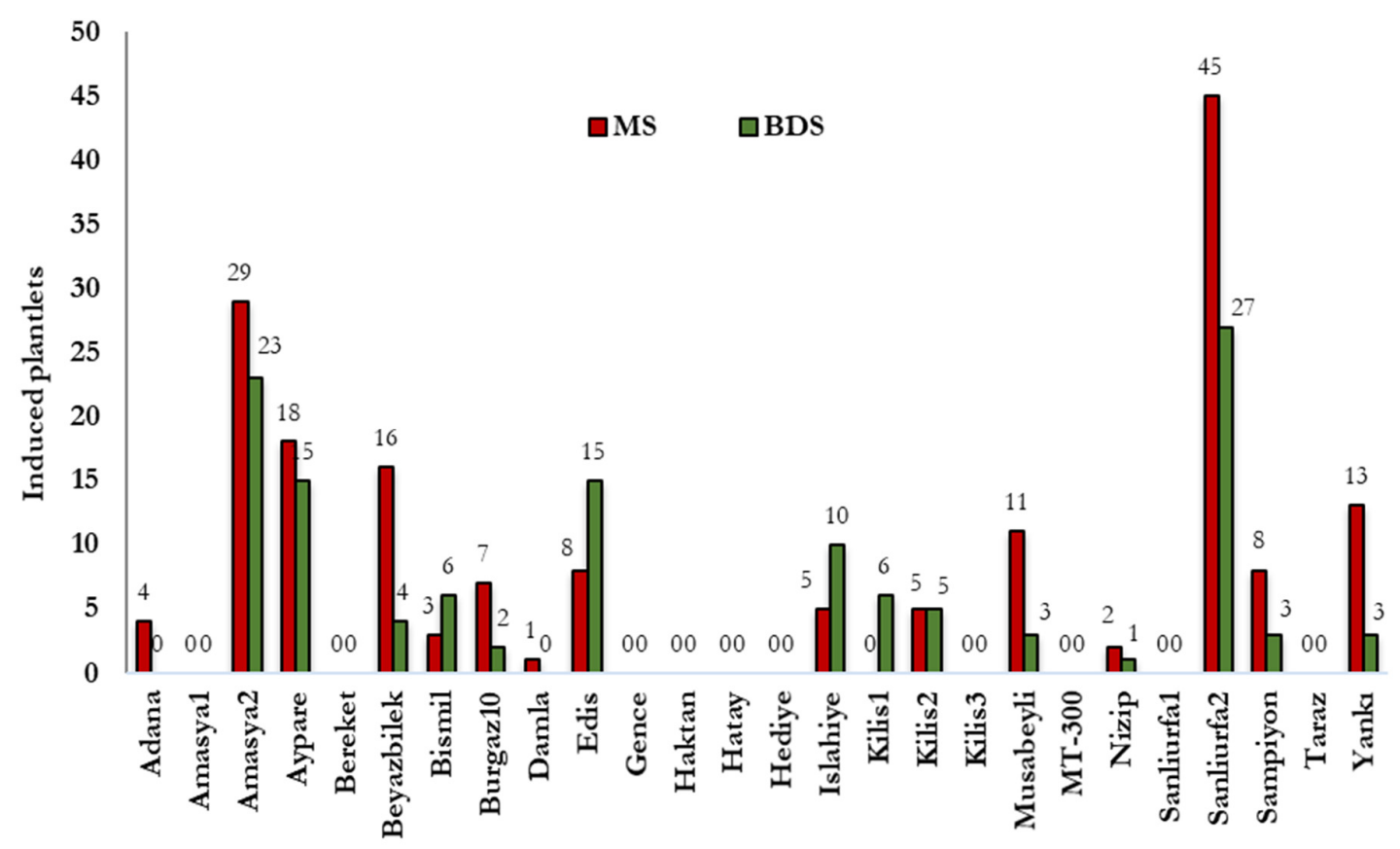

Figure 3. The number of induced plantlets on BDS and MS medium 
Amount of Nuclear DNA

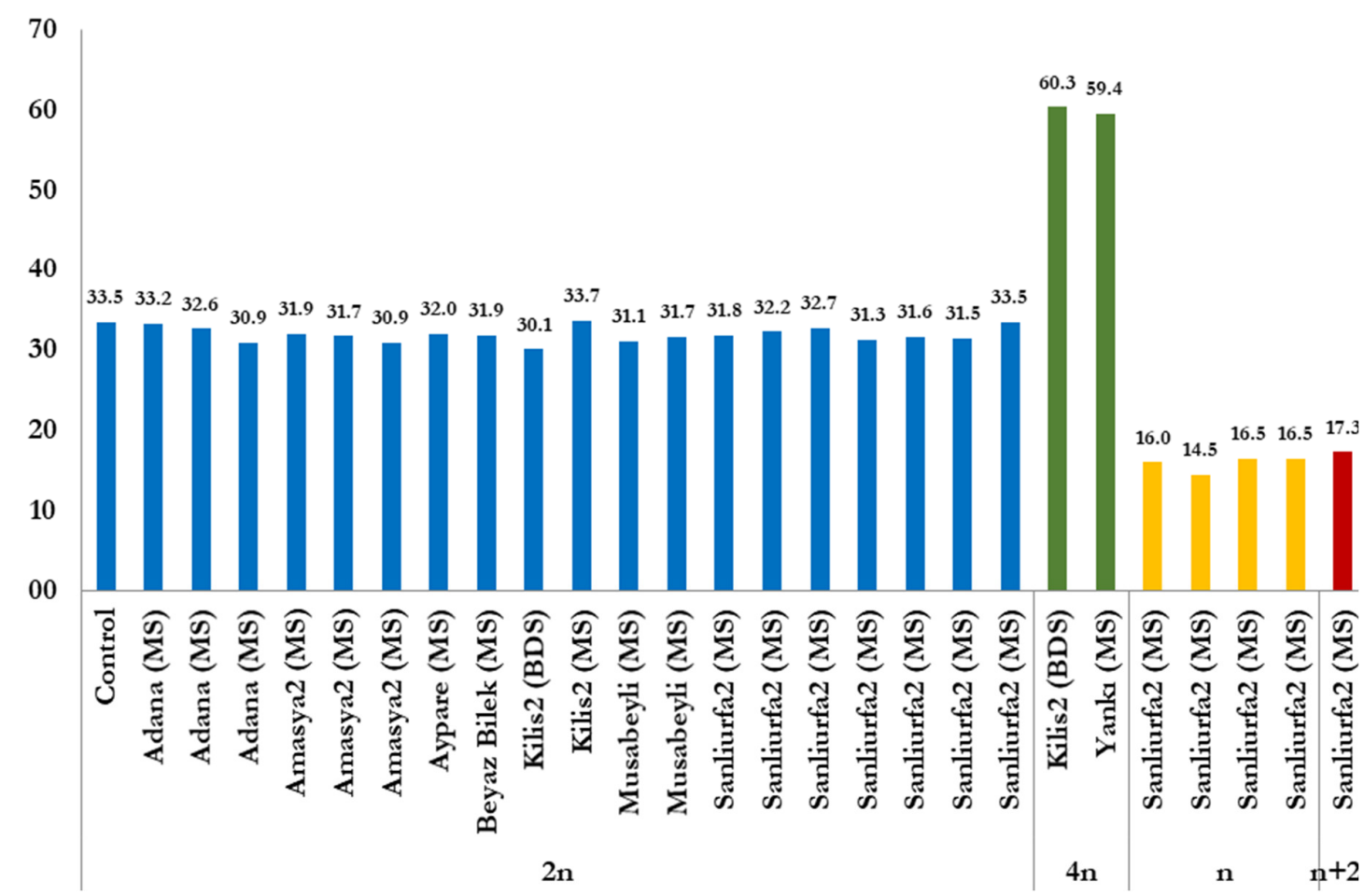

Figure 4. Ploidy level of in vitro plantlets

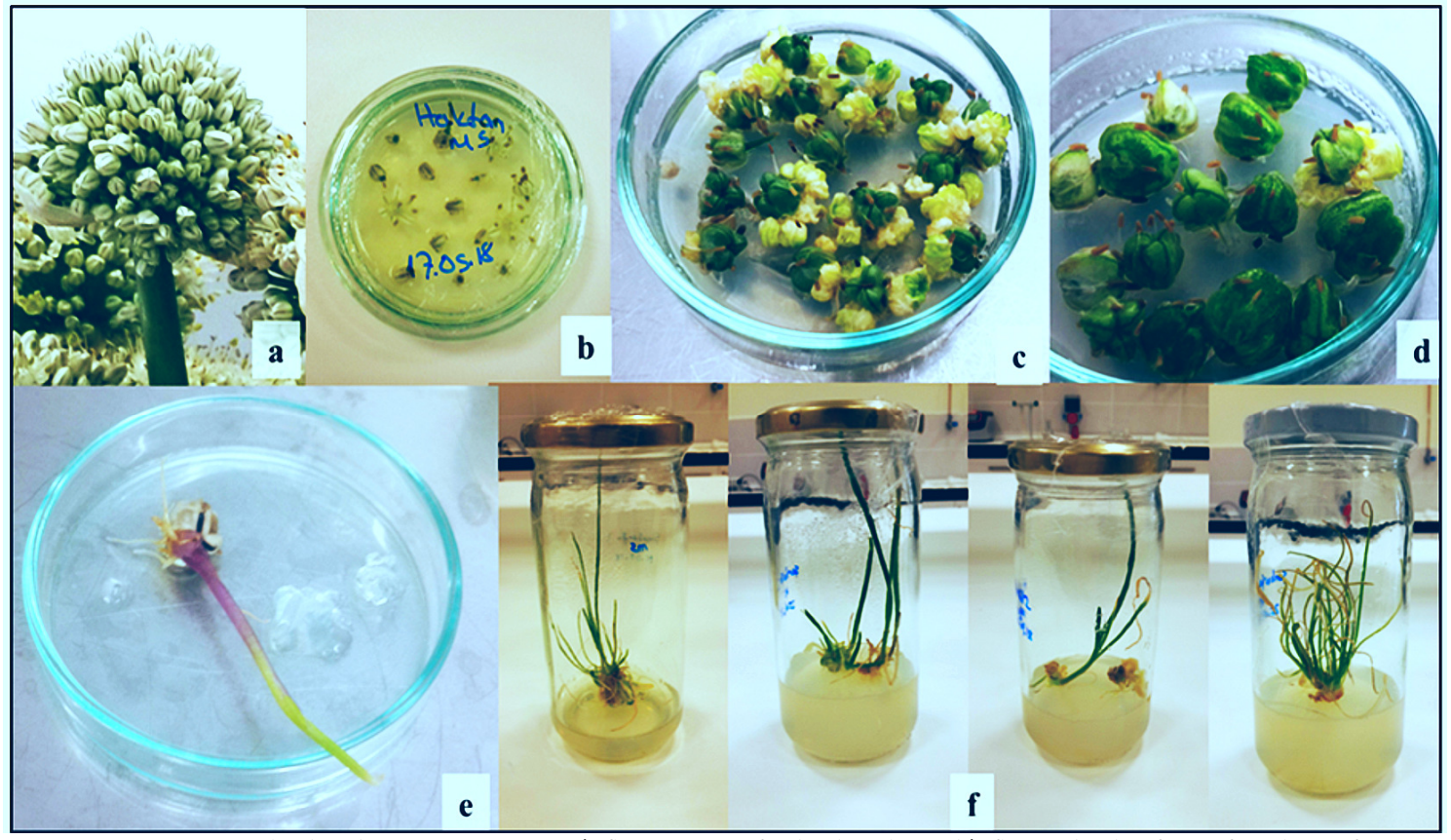

Figure 5. Haploid induction in onion: a) flower stage for bud picking, b) flower buds after a few days of inoculation, c) callus formation in flower buds, d) normal and hyperhydric buds, e) direct plantlet induced, f) in vitro plantlets 


\section{Discussion}

Culture media is one of most the important factors affecting haploid production in onion. The highest percentage of induced plantlets and callus induction were observed as $12 \%$ and $20 \%$ and $20 \%$ and $21.8 \%$ in BDS and MS medium, respectively. Therefore, when the number of callus and induced plantlets based on, it can be said that MS medium was better than BDS medium depend on used plant material (Figure 3 ). In the $t-$ test performed to determine the differences between BDS and MS medium, it was observed that the effect of MS medium on the number of callus and induced plantlets was important. Mathapati et al. (2019) investigated to determine effects of B5 and MS medium on gynogenesis efficiency in tropical short-day onion. The authors found that in B5 medium, the highest induction efficiency was observed as 1.9\%, whereas in MS medium, the highest induction frequency recorded as 5.0\%. Similarly, Campion et al. (1992) stated that MS medium was the most suitable medium for obtaining haploid embryos for onion gynogenesis studies.

Genetic factors are believed to be very important for the achievement of gynogenesis formation. Indicating of gynogenesis is strongly affected by the genotype. Percentage of gynogenic induction, callus formation and enlarged buds (plumpy) varied depend on locally grown genotypes and open-pollinated onion cultivars. Low regeneration frequency can be attributed to poor gynogenic efficiency and genotype structure. Both the highest percentage of induced plantlets (20\%) and callus induction (21.8\%) were recorded in Sanliurfa 2 (Table 1). As evident from Figure 3, the highest numbers of induced plantlets were obtained from genotype Sanliurfa 2 as 27 plantlets on BDS medium and 45 plantlets on MS medium. Bohanec and Jakse (1999) analyzed onion accessions from Europe, Japan and North America and they found that very high variability was found among cultivars and inbred lines. Michalik et al. (2000) studied onion gynogenesis in 30 Polish onions on different media. They reported that the yield of embryos strongly depended on the genotype and among plant material 9 (30\%) were unresponsive to gynogenesis, 12 (40\%) produced 0.2\%- $0.8 \%$ embryos. Anandhan et al. (2014) stated that variation in gynogenic efficiency was observed among genotypes and also found that gynogenic potential of long-day accessions belonging to USA was higher than short-day India's onion accessions. In a research conducted on Spanish onion germplasm, the results showed that the percentage of gynogenesis induction and the percentage of embryogenesis varied depended on the cultivar. In the same study, gynogenic efficiency of American $\mathrm{OH}-1$ populations was found to be $15 \%$ higher than Spanish germplasm (Fayos et al., 2015). 22 onion varieties from different regions around the World including populations, inbreeds, synthetics and clones were used as plant material by Geoffriau et al. (1997) to test for their gynogenesis ability. They found that plant regeneration ranged from 0 to $17 \%$ and from 0 to $11 \%$ of cultured flowers, respectively. The highest results were obtained from inbreeds and synthetics for embryo production as well as for plant regeneration. On the other hand, the gynogenic potential of the open-pollinated onion cultivars was lower than locally grown onion genotypes, which are inconsistent with previous reports by Khar et al. (2018).

\section{Conclusions}

Media composition and genetic factors are believed to be very important for the achievement of gynogenesis induction in onion. In this study, it was determined that media composition and genotype were effective on both callus formation and gynogenesis induction. MS medium was found to be more successful in increasing the efficiency of the number of callus and induced gynogenic plantlets for used plant material. The frequencies of gynogenic plantlet development also varied among the genotypes. It was observed that locally grown onion genotypes were more responsive to gynogenesis than open-pollinated onion cultivars. All haploid plants were obtained from the Sanliurfa 2 genotype. 
Yarali Karakan F (2020). Not Bot Horti Agrobo 48(3):1176-1184

\section{Acknowledgements}

This research received no specific grant from any funding agency in the public, commercial, or not-forprofit sectors.

\section{Conflict of Interests}

The author declares that there are no conflicts of interest related to this article.

\section{References}

Alan AR, Mutschler MA, Brants A, Cobb E, Earle ED (2003). Production of gynogenic plants from hybrids of Allium cepa L. and A. roylei Stearn. Plant Science 165(6):1201-1211. https://doi.org/10.1016/S0168-9452(03)003273

Alan AR, Zeng H, Assani A, Shi WI, McRae HE, Murch SJ, Saxena PK (2007). Assessment of genetic stability of the germplasm lines of medicinal plant Scutellaria baicalensis Georgi (Huangqin) in long-term, in vitro maintained cultures. Plant Cell Reports 26:1345-1355. https://doi.org/10.1007/s00299-007-0332-9

Alan AR, Kaska A, Arslan E, Celebi Toprak F (2017). Turkish doubled haploid onion (A. cepa L.) lines. In: The 3rd International Symposium on EuroAsian Biodiversity. Minsk, Belarus pp 114.

Anandhan S, Chavan AA, Gopal J, Mote SR, Shelke PV, Lawande KE (2014). Variation in gynogenic potential for haploid induction in Indian shortday onions. Indian Journal of Genetics and Plant Breeding 74(4):526-528. https://doi.org/ 10.5958/0975-6906.2014.00883.9

Bohanec B, Jakse M (1999). Variations in gynogenic response among long-day onion (Allium cepa L.) accessions. Plant Cell Reports 18: 737-742. https://doi.org/10.1007/s002990050652

Campion B, Azzimonti MT, Vicini E, Schiavi M, Falavigna A (1992). Advances in haploid plant induction in onion (Allium cepa L.) through in vitro gynogenesis. Plant Science 86:97-104. https://doi.org/10.1016/01689452(92)90183-M

Dhatt AS, Thakur P (2014). Production of doubled haploids in onion: A review. Journal of Horticultural Sciences 9(2):107-112. https://jhs.iihr.res.in/index.php/jhs/article/view/178

Dunstan DI, Short KC (1977). Improved growth of tissue cultures of the onion (Allium cepa). Physiologia Plantarum 41:70-72. https://doi.org/10.1111/j.1399-3054.1977.tb01525.x

Fayos O, Valles MP, Garces Claver A, Mallor C, Castillo AM (2015). Doubled haploid production from Spanish onion (Allium cepa L.) germplasm: embryogenesis induction, plant regeneration and chromosome doubling. Frontiers in Plant Science 6:384. https://doi.org/10.3389/fpls.2015.00384

Gamborg OL, Miller RA, Ojima K (1968). Nutrient requirements of suspension cultures of soybean root cells. Experimental Cell Research 50:151-158. https://doi.org/10.1016/0014-4827(68)90403-5

Geoffriau E, Kahane R, Rancillac M (1997). Variation of gynogenesis ability in onion (Allium cepa L.). Euphytica 94:3444. https://doi.org/10.1023/A:1002949606450

Jakse M, Hirschegger P, Bohanec B., Havey MJ (2010). Evaluation of gynogenic responsiveness and pollen viability of selfed doubled haploid onion lines and chromosome doubling via somatic regeneration. Journal of the American Society for Horticultural Science 135:67-73. https://doi.org/10.21273/JASHS.135.1.67

Khar A, Kumar A, Islam S, Kumar A, Agarwal A (2018). Genotypic response towards haploid induction in short day tropical Indian onion (Allium cepa). Indian Journal of Agricultural Sciences 88 (5):709-713. http://epubs.icar.org.in/ejournal/index.php/IJAgS/article/view/80058

Mathapati GB, Kalia P, Islam S, Saini N, Kumar A, Khar A (2019). Influence of culture media and their compositions on haploid induction in Indian short-day onion. Proceedings of the National Academy of Sciences, India Section B: Biological Sciences 89:739-746. https://doi.org/10.1007/s40011-018-0990-0

Michalik B, Adamusa A, Nowak E (2000). Gynogenesis in Polish onion cultivars. Journal of Plant Physiology 156(211216). https://doi.org/10.1016/S0176-1617(00)80308-9 
Murashige T, Skoog F (1962). A revised medium for rapid growth and bio assays with tobacco tissue cultures. Physiologia Plantarum 15:473-497 https://doi.org/10.1111/j.1399-3054.1962.tb08052.x

Sahinalp S, Yarali Karakan F (2019). Yerel soğan genotiplerinin haploidiye yatkınlığının belirlenmesi, [Determination of haploidy frequencies of the locally grown onion (Allium cepa L.) genotypes]. Turkish Journal of Agricultural Research 6(2):186-192. https://doi.org/10.19159/tutad.523682

Yarali F, Yanmaz R (2013). Allium türlerinin sslahında haploidi tekniğinden yararlanma [Utilization of haploidy techniques in breeding of Allium species]. Türk Bilimsel Derlemeler Dergisi 6(2):44-50 http://derleme.gen.tr/index.php/derleme/article/view/208/206

Yarali F, Yanmaz R (2017). The effects of plant growth regulators on in vitro gynogenic embryo formation in onion (Allium cepa L.). African Journal of Biotechnology 16(40):1977-1983. https://doi.org/10.5897/AJB2017.16091

Yarali Karakan F (2019). Influence of cold pretreatments on callus and embryo induction in onion (Allium cepa L.) via flower bud culture. Fresenius Environmental Bulletin 28(11):8070-8075 file://C:/Users/User/Downloads/FEB_11_2019_Pp_7674-8322\%20(2).pdf
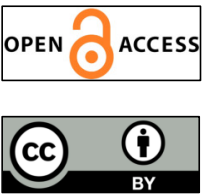

The journal offers free, immediate, and unrestricted access to peer-reviewed research and scholarly work. Users are allowed to read, download, copy, distribute, print, search, or link to the full texts of the articles, or use them for any other lawful purpose, without asking prior permission from the publisher or the author.

License - Articles published in Notulae Botanicae Horti Agrobotanici Cluj-Napoca are Open-Access, distributed under the terms and conditions of the Creative Commons Attribution (CC BY 4.0) License.

(C) Articles by the authors; UASVM, Cluj-Napoca, Romania. The journal allows the author(s) to hold the copyright/to retain publishing rights without restriction. 